\title{
Study Travels in Theory and Practice: The Sweden-America Foundation and Its Fellows to the U.S., 1919-1939
}

\section{Andreas Melldahl}

Uppsala University

\begin{abstract}
This article describes and discusses the first 20 years of the history of the Sweden-America Foundation, 1919-1939. The main focus of the Foundation during this time was to establish an exchange of scholars, students, and professionals across the Atlantic Ocean. An analysis of this fellowship program is the main focus of the article. Different kinds of fellows of the Foundation are distinguished and their time in the U.S. is examined. The most important of the categories were "free studies" and the "Industrial Fellows." In both of these categories, a link to the needs of Swedish trade and economy is discerned through a large, and over time increasing, proportion of a practical emphasis of the fellows' studies in America. Moreover, the Foundation's position in Sweden is discussed. Through an agreement between the Foundation and the American authorities, the Sweden-America Foundation became the gatekeeper for Swedes who sought to study and travel in America. For the Foundation, a carefuland strategic-selection of its fellows was a way to act in the Swedish national interest.
\end{abstract}

Keywords: Sweden-America Foundation-transatlantic contacts-transnational education-education and economy-interwar period-Sweden and America 
This article ${ }^{1}$ deals with the Sweden-America Foundation and its fellows. ${ }^{2}$ Since the inception in 1919 and throughout its history, the emphasis of the work of this Swedish foundation has been to establish and expand an exchange of scholars, students, and trainees between Sweden and North America (predominantly the United States, and after World War II, Canada as well.) The article will focus on the first two decades of the history of the Foundation, 1919-1939, which is a period when the connections to the U.S. were formalized, and the number of travellers was low enough to allow a more thorough investigation of the individual travels. Moreover, it was during this time that the Foundation established itself as a key factor in Swedish-American relations, something that also resulted in a specific self-conception, according to which the Foundation acted with the good of the nation before its eyes.

The main focus of what follows will be to examine and discuss the content of the fellows' travels and the fellowship programs of the SwedenAmerica Foundation. Where did their fellows go and how did they put their time in America to use? What kinds of fellowships did the Foundation offer and to what kinds of fellows were they awarded? To understand the Foundation one also has to ponder the second part of its name, the SwedenAmerica Foundation. Why America? What were the benefits of sending, mostly young, Swedish scholars and professionals to the U.S.? It is likely that any answers to the question of what the travellers did during their time in America also can shed some light on why America was considered a desirable partner of exchange.

\section{A Foundation for Closer Ties between Sweden and America}

If you take part of documents those involved with founding the Foundation in 1919, you learn that the United Stated started to attract attention after World War I "due to its great technical development and its natural resources," which made it important to establish "closer connections to this

1 Comments on the article have been given by Dag Blanck, Mikael Börjesson, and Anders Brunelius, to all of whom I am sincerely grateful. Translations of Swedish texts into English are my own.

2 For a history of the Sweden-America Foundation, see Dag Blanck, Sverige-Amerika Stiftelsen. De första sjuttio åren 1919ñ1989 (Stockholm 1989) and Andreas Melldahl, Västerled tur och retur: Del I: Utbildning och ekonomi. En ekonomhistorisk studie av Sverige-Amerika Stiftelsens stipendieverksamhet 1919-2006 (Uppsala 2008, available at http://www.skeptron.uu.se/ broady/sec/secreports.htm). 
land of the future in the west." As an answer to this call a preliminary decision was reached, during a meeting in Stockholm in February 1919, to form an organization with the purpose of "promoting the exchange of scientific, cultural and practical knowledge" across the Atlantic Ocean. The meeting gathered a group of prominent academics, public figures and industrialists, the "heights of our cultural and economic worlds," and on June $2^{\text {nd }}$ the same year, the Sweden-America Foundation was born. Students were ready to leave for the U.S. immediately, as funds already had been raised in both Sweden and the U.S. to enable Swedish students and educated individuals to study in America. Representatives of the Foundation stated that it was to "the new generation - the youth - that the efforts should be directed." ${ }^{3}$ It was also this task - the constitution, continuation, and expansion of the fellowship program - that would continue to be the key mission of the Foundation and the base of its role and function in Swedish society. ${ }^{4}$

\section{Fellowship Programs between Theory and Practice}

Altogether 308 persons were awarded grants from the various fellowship programs of the Sweden-America Foundation between 1919 and 1939. ${ }^{5}$ Out of the 308,70 per cent travelled as the Foundation's own fellows, 16 per cent as Industrial Fellows, and 10 per cent as college students; the residual 4 per cent was made up by Honorary Fellows and Summer Fellowshipstwo smaller, less frequent, categories of fellowships. Figure 1 below shows how the numbers of the different categories varied over the period. Variations in the available funds for fellowships naturally led to a change in the numbers awarded. The most stable category was the Foundation's own fellowships, with an average of ten fellowships awarded annually. Among the other groups, the Industrial fellowships, which above all were available in two portions during the 1920 s, were the most prominent. The college

3 Sweden-America Foundation, Sverige-Amerika Stiftelsens jubileumsskrift 1919-1929 (Stockholm 1929), p. 14.

4 A thorough discussion of the reasons and strategies behind the founding of the Foundation can be found in Dag Blanck's contribution, "Scholars across the Seas," in this issue.

5 The total sum of fellowships awarded is somewhat larger, most apparent in the Foundation's own calculations of this period, partly due to the fact that a few individuals were appointed twice with different fellowships and partly because some of the fellowships were perennial. The Foundation count, for example, has as many as 104 recipients of Industrial fellowships during the inter-war period, while in my investigations I have encountered only 49. See Sweden-America Foundation, Arsberättelse 1943 (Stockholm 1943), p. 25. 
students were, for the whole period, few and far between, something which was even truer for the smallest categories, the Honorary Fellows and the Summer Fellowships. Below I will describe and discuss the various categories more in depth and give special attention to the two largest ones.

Figure 1: Number of fellows per category of fellowship, 1919-1939

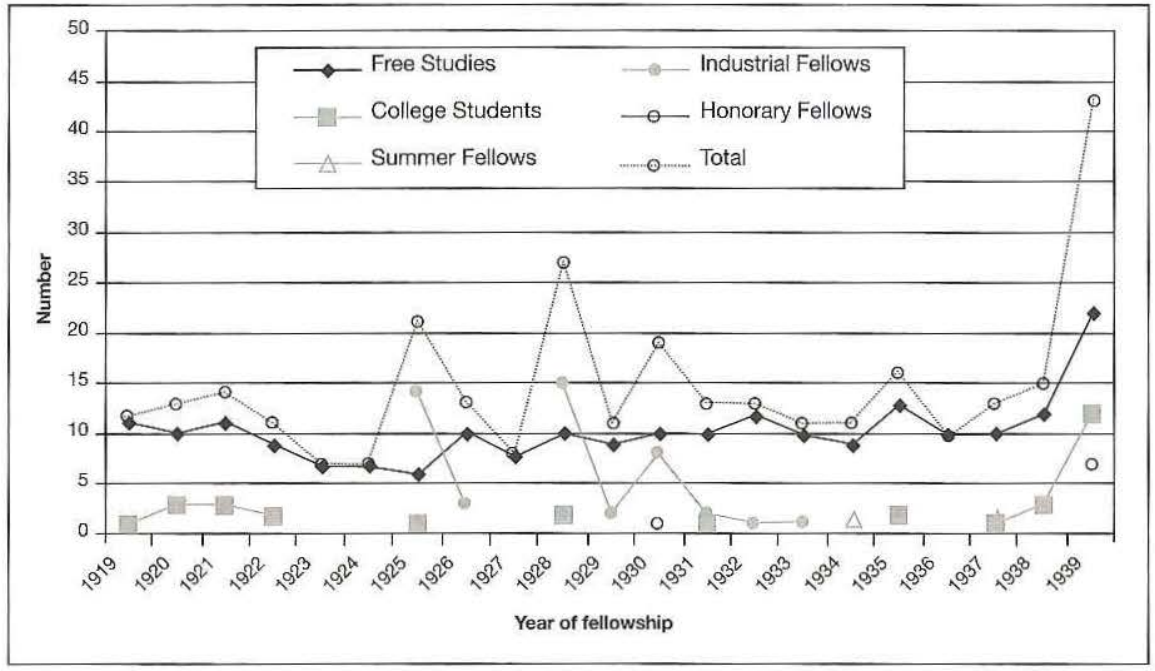

Sources: Sweden-America Foundation Annual Reports 1919-1939; Sweden-America Foundation, Alumni Register; American Scandinavian Foundation Annual Reports, 1920-1939.

\section{Free studies? The Zorn and University Fellowships}

As can be seen in figure 1, the Foundation's own fellowships, to be used for university studies, dominated in the fellowship programs from 1919 to 1939. These fellowships were described by the Foundation as free studies. ${ }^{6}$ They are here identified as the Foundation's own fellows as they were funded by the Foundation alone, with money donated to the Foundation either as established fellowship funds or through annual financial contributions from various Swedish companies or individuals. The Zorn fellowship 
fund, for example, had its base in a donation from 1919 of SEK 100,000 by the Swedish painter Anders Zorn. This fellowship was considered the most prestigious of the fellowships and accepted older applicants than the other funds, with an age limit of 45 years instead of 35. During the period focused in this article, the Zorn fellowship was awarded to individuals who had reached positions of more prominence in society, while the university fellowships were aimed at younger scholars. Both the Zorn fellowship and the university fellowships were to be used (as the statutes for the Zorn fellowship states) "as travel assistance for Swedish citizens, who wish to pursue studies in any subject, preferably scientific, at the location best suited for such an undertaking."7 They were consequently free in the sense that the Foundation did not stipulate the kinds of studies to be pursued or where they should take place (other than "at the location best suited.") Generally, the fellowships were highly sought after, with about 90 applicants each year, and an average of ten fellowships offered. ${ }^{8}$

It is in this category of fellowships where we find the greatest difference between the Foundation's activities of today and during the inter-war period. Today, most - if not all - fellows travel to the U.S. (or Canada) as a step in their work on their doctoral thesis, or as post-docs. These studies are therefore highly theoretical and/or empirical investigations as a part of formalized research. This was not always the case for the fellows in the $1920 \mathrm{~s}$ and 1930s. Although almost all of the fellows of this period donned the jacket of the academic or the student, the contents of their travels give the term "studies" a much wider - and less theoretical-definition. For some, the studies were made up of practical work at an American firm or institution, while others were more what one would call study travels, all over the American continent.

A closer investigation of the fellows' travels in the U.S. shows the different purposes or the main contents of the travels among the organization's own fellows 1919-1939 (see table 1 below). Three categories of fellows emerge, namely studies, study travels, and work practice. These categories are not obvious from the first look at the listings of the Sweden-America

7 Sweden-America Foundation, Årsberättelse 1935 (Stockholm 1935), p. 29.

8 The highest number of applicants to the Zorn and university fellowships is to be found in 1935, with 130 candidates for 12 available fellowships, and in 1927, when eight fellowships were offered, we find the lowest number with 60 . A clear trend in the numbers of applicants is, however, hard to discern, since they varied greatly from year to year. See Sweden-America Foundation Annual Reports 1919-1939. 
Foundation fellows but require a closer examination of the archival records of the Foundation and its fellows' travel accounts. As can be seen from the table, the percentages for studies and study travcls are of similar size, while the number of fellows who used the main part of their time in the U.S. to work or practise was smaller. If the groups for Study Travel and Work/ Practice are combined, it can be concluded that most of the fellows on free study-fellowships did not, in fact, spend their time in America engaged in contemporary university-style theoretical studies. The practical emphasis of the Sweden-America Foundation fellowship program was thus very important from the very beginning and has remained so, even though the theoretical side has been strengthened during the $20^{\text {th }}$ century. In what follows, the practical side will therefore receive some special attention.

\section{Table 1: Purpose of travel for fellows on fellowships for free studies from the Sweden-America Foundation, number and per cent, 1919-1939}

\begin{tabular}{lcc} 
Purpose of Travel & Number & Per cent \\
\hline Studies & 107 & 50 \\
Study Travel & 99 & 46 \\
Work/Practice & 10 & 5 \\
\hline Sum & 216 & 100
\end{tabular}

Sources: Sweden-America Foundation, Annual Reports 1919-1939; Sweden-America Foundation, Alumni Register; Utdrag ur rapporter frän Sverige-Amerika Stiftelsens stipendiater (Stockholm 1924); Sverige-Amerika Stiftelsen. Jubileumsskrift 1919-1929 (Stockholm 1929); Royal Library, Stockholm: "Sverige-Amerika Stiftelsen"; American-Scandinavian Foundation, Annual Reports 1920-1939.

In the category of studies, fellows who followed theoretical education at universities or other research institutions as well as those who conducted basic research have been included. One example is a fellow from 1931 who visited several American observatories for his work with "photometrical studies of the spectra of stars," another from 1921 who wanted to acquire an "overview of older Palaeozoic formations in the United States," and a third from 1925 who studied "the problem of liquidity in savings banks." Those who preferred to study at universities did so at altogether 27 different-and mostly highly prestigious - institutions. Sorted by frequency, the 
most visited were Harvard University (21 fellows,) Massachusetts Institute of Technology, MIT (13 fellows) and Columbia University (11 fellows.) Other universities that received Sweden-America Foundation fellows include the University of Wisconsin, Yale University, Dartmouth College, and Iowa State College. The subjects that fellows studied varied according to their respective destinations. Among the Ivy League universities, Harvard attracted fellows in a wide array of disciplines, technology, as well as natural sciences and the humanities. Columbia was especially popular for studies in the social sciences and the humanities, while Yale was preferred by fellows in medicine. The small, but highly regarded, Dartmouth College attracted several fellows in the early 1920s to its Amos Tuck School of Finance (later renamed School of Business Administration), where Scientific Management according to the principles of Taylor was taught. At the University of Wisconsin and Iowa State College the Swedish fellows were mostly engaged in agricultural studies, and students at MIT favoured technology.

The second largest group of the Foundation's own fellowship winners chose to use their time in America for study travels. This category is as varied in its contents as the other, but its fellows often visited several locations and-most significantly - never, or for only a minor part of their time, conducted any formal studies at established educational or research institutions, or gathered information for academic research. Academic institutions could very well be a destination for this group, but then the primary focus was on how education or research was organized at the institution, rather than on the actual research conducted. One fellow who in 1932 spent some time at Cornell University did so to learn how Home Economics as a subject was taught and what curriculum that was used. Yet, most of these fellows travelled to non-academic destinations, such as factories, public schools, federal or state bureaus, commercial offices, etc., but with similar kinds of questions. Fellowship winners in this category were thus oriented toward investigating American praxis: how knowledge-based institutions were organized, or how industrial and non-industrial processes were structured.

Fellows whose primary goal dealt with working and/or gaining practical experience in the U.S. generally visited a private or public company or institution to work or in other ways take part in the day-to-day operations. These fellows can also be called trainees or interns. Although a program of "Industrial Fellows" was started in 1925, this category of fellows had been part of the exchange from the very beginning in 1919. In that year, for 
instance, one fellow went across the Atlantic Ocean to be an intern at a New York City bank. However, a couple of fellows in the free studies-category were de facto interns even after the Industrial Fellow-program had been constituted.

The relative significance of the three subcategories among the Foundation's fellows for free studies changed over time. Fellowships for work/ practice had its fairly small but steady share in the very beginning of the period. With regard to the other two, the share of the study travel-fellows increased, at the expense of studies. From 1919 to 1928, studies were more common than study travels, but after 1929 the balance shifted, and study travels became more prevalent.

\section{Industrial Fellows}

The Industrial fellowships, or the "technical and commercial fellowships" as they sometimes were referred to, were above all available to applicants in two periods during the 1920 s, but were offered in the 1930 s as well, albeit less frequently, and in far smaller numbers. The fellowship program was the result of an active and diligent search for economic support for the Foundation's programs in the U.S. by AGA director and vice president of the board, Axel Robert Nordvall, and the chairman of the AmericanScandinavian Foundation, the Foundation's counterpart in America. As a consequence, a number of American companies and institutions agreed to accept "highly qualified young Swedish men" as short-term employees in order to give them further American experiences. ${ }^{9}$ In 1925, 14 individuals were awarded fellowships, and during the next several years, from 1926 to 1930, 23 Industrial Fellows were appointed. After that, the program was cancelled, something which the Foundation lamented in its annual reports for more than a decade. The prime reason for the cancellation was the economic depression in America starting with the crash of the Wall Street stock market in 1929, as many former American host companies for Industrial fellows maintained that it was their "national duty" to give any available jobs to Americans, instead of Swedes. ${ }^{10}$

Different kinds of companies took part in the Industrial fellows program, and the awardees worked at several departments of the companies in or-

9 Sweden-America Foundation, Årsberättelse 1926 (Stockholm 1926), p. 3.

10 Sweden-America Foundation, Årsberättelse 1930 (Stockholm 1930), p. 3. 
der to get to know their organization and operations. Prior to its formal launching, two banks in New York offered places for Swedes from 1919 to 1924 , and banks continued to be the most common places of work during the program's short but intense time of blooming. In addition, insurance companies, paper industries, energy plants, department stores, federal bureaus (in forestry science,) libraries, and hospitals invited Swedish fellows. Libraries and hospitals also gave women opportunity to participate, and the fellowships at hospitals were exclusively for female applicants. Out of the 49 individuals who have been classified as Industrial fellows, 86 per cent were appointed between 1925 and 1930. After 1930, the hospital fellowships were the only fellowships which continued to be awarded, but in very modest numbers. ${ }^{11}$

\section{College Students, Honorary Fellows, and Summer Fellows}

Among the smaller categories of fellowships, the college fellowships were the largest. During the period, the Foundation from time to time received scholarship offers from American universities for Swedish students to study at the undergraduate level. The selection of the applicants to these positions was made by the American-Scandinavian Foundation in New York, which also communicated with the universities. ${ }^{12}$ In addition to this arrangement, an exchange program was also used to finance studies in the U.S. for young Swedes, through which they were guaranteed a place at an American college with housing in a family, if a reciprocal arrangement could be organized in Sweden. From what the sources tell us, the college students' studies seem to have been entirely academic.

The Honorary Fellows were persons who for one reason or another wanted to travel or study in the U.S. and had been granted financial support by some other institution or had funds of their own. If the Foundation judged them to be qualified, they could attain the status as a Sweden-America Foundation Honorary Fellow and thereby get help with visa to the U.S. in a similar fashion as the other Foundation fellows. An Honorary Fellow had to fulfil the academic standards set for the university fellowships. ${ }^{13}$

Finally, there were, on two occasions in the mid 1930s, fellowships open

11 Sweden-America Foundation, Anmual Reports 1925-1939.

12 Siveden-America Foundation, Årsberättelse 1920 (Stockholm 1920), p. 8.

13 Sweden-America Foundation, Årsberättelse 1933 (Stockholm 1933), pp. 5-7. 
for two applicants, for studies at Bryn Mawr College, a small high-status Liberal Arts College for female students outside Philadelphia. These fellowships, which in the records are labelled "summer school fellowships" or in short Summer Fellowships, signified courses dealing with social issues for female industrial workers. The Foundation contributed financially to the fellows' travel costs, while Bryn Mawr paid for all tuition fees and lodging costs. ${ }^{14}$

\section{The Foundation in Sweden}

So far, I have described and discussed the various categories of fellows of the Sweden-America Foundation. In what follows, the Foundation's position in Sweden, its choice of fellows and how its American orientation can be understood will be discussed.

A particular self-image developed at the Sweden-America Foundation throughout the period of study, although especially in the 1920s, as it began to see itself as the central institution in Swedish-American relations. This is noticeable both in the annual reports and the discussions of the board of directors. When the Foundation's tenth anniversary was marked in 1929, the vice president of the board, Axel Robert Nordvall, noted the unique position the Foundation had come to occupy through its agreement with the American authorities:

The agreement, ... according to which ... fellows ... from the Foundation were given the right to stay in America for studies during one to two years outside the official quota [an agreement which is still respected,] is one of few possibilities that now remain for young Swedish men and women, who wish to improve their knowledge in their respective field in the U.S. ${ }^{15}$

The Foundation thus served as a gatekeeper to studies and study travels in America. This quasi-monopolistic position meant that the Foundation viewed itself as the Swedish representative vis-à-vis the U.S., not just as a mediator of temporary studies and travels, but an institution speaking in the Swedish national self-interest. By carefully and strategically selecting its fellows, the Foundation thus served the nation. "The importance for the individual as well as for our country," the Foundation wrote in 1936, "of 
the Foundation's fellowships should be well-known and accepted today."16 This role is effectively illustrated in a discussion of an application from an engineer in 1923, who wished to travel to America to study the petroleum industry. The engineer was turned down by the board of directors, not because of his own merits, but because they judged that Sweden had little chances of "acquiring transoceanic assets of petroleum." The engineer could, however, "become useful for us in the future," not in relation to the United States, but rather in "the Russian market."17

One reason for the care which the Foundation took in selecting candidates for the fellowships is the fact that the United States was considered a paragon, from where inspiration could be found for areas where Swedish knowledge and technology lagged behind. ${ }^{18}$ During the 1920 s and 1930 s, the Foundation primarily supported fellows whose American experiences could be put to use in Sweden. Many of the board members were persons of influence, well aware of the conditions for Swedish trade and industry. Members knew, for instance-in a discussion of the applicants of the year 1925 - that during the last " 30 years no Swedish fishery representative has been to America," and since America has a lot to offer in this subject [technical studies of fisheries], it was important to send a fellow there and then "spread this both useful and highly needed knowledge here at home in Sweden." knowledge was even expressed through detailed descriptions of the observations needed and the specific knowledge sought. ${ }^{20}$

Prior to the founding of the Sweden-America Foundation in 1919, Germany had occupied the most prominent position on the Swedish academic and cultural mental maps, with a long history as a source of inspiration both for higher education and business life. In the early $20^{\text {th }}$ century, the United States emerged as another significant point of reference for Sweden. In cer-

16 Sweden-America Foundation, Årsberättelse 1936 (Stockholm 1936), p. 3.

17 National Archives, Stockholm, Sverige-Amerika Stiftelsens arkiv, A2: "Styrelseprotokoll med bilagor",

"Arbetsutskottets sammanträde" 23 February 1923.

18 Because the international experiences of the late $19^{\text {th }}$ and early $20^{\text {th }}$ centuries had shown the increasing importance of an effective industrial sector, it was considered essential to bridge or at least reduce the gap with America, so as to decrease the Swedish emigration. See Nils Runeby, "Americanism, Taylorism and Social Integration,” Scandinavian Journal of History (1978: Volume 3, No. 1), pp. 21-46.

19 National Archives, Stockholm, Sverige-Amerika Stiftelsens arkiv, A2: "Styrelseprotokoll med bilagor", "Arbetsutskottets sammanträde" 21 April 1925.

20 Cf. National Archives, Stockholm, Sverige-Amerika Stiftelsens arkiv, A2: "Styrelseprotokoll med bilagor", "Arbetsutskottets sammanträde" 23 February 1923. 
tain fields of study, such as technology and management, and in the sphere of practical experiences, the United States was considered particularly important. In this way, the U. S. became a complement to the traditional patterns of contact with Germany. According to Nils Runeby, the U.S. - and the U.K. - were thought to have an economic advantage due to their rich natural resources and highly developed and productive industries, making Germany a more suitable inspiration for the organization of theoretical study. ${ }^{21}$ The Foundation's propensity to award fellowships with a practical emphasis should be seen in the light of this Swedish-American-German triangle of contacts. Fellowship winners of this kind, with a Swedish educational - and sometimes professional - background, were good candidates to learn more about American industrial and administrative efficiency and bring this knowledge back to Sweden. ${ }^{22}$ The present article shows that this propensity was sustained, and even strengthened, throughout the inter-war period.

A movement towards is also a movement away from something. In the case of the U.S., as a new recipient in the international exchange of students, scholars, and trainees, it was not necessarily a shift away from Germany, as much as a complement to Germany. This is particularly true for the many students in technology, or for those Swedes who studied organizational theory or Scientific Management at Dartmouth College. Some of the more academic travellers, such as for example the many astronomers who visited American observatories during the 1920s, could, however, also be understood through this framework. Due to the technological development of the United States, the observatories had been equipped with state-

21 Nils Runeby "Tyskland som teknisk förebild" in (Eds: Bernd Henningsen et al.) Skandinavien och Tyskland 1800-1914: Möten och vänskapsband (Stockholm 1999), pp. 389-390. This article challenges the view that America and England were held as the major examples of industrial and technological development in early $20^{\text {th }}$ century Sweden. Germany was seenówith the same argument advanced in support of German higher educationóas a more useful model, because its economic circumstances were similar to Sweden's.

22 To follow one of the arguments in my previous studies of the Sweden-America Foundation, it could be fruitful to apply the structural economic historical perspective of Lennart Schön to the exchange of fellows across the Atlantic Ocean. According to this view, during the time of the inception of the Foundation, the Swedish economy had started to be structured around industries through the gradual implementation of a cluster of important innovations derived from the second industrial revolution. The period after World War I up until about the stock market crash was a structural phase of radicalization of the economy, where higher efficiency was being sought. Cf. Melldahl (2008) and also Lennart Schön, En modern svensk ekonomisk historiaóTillväxt och omvandling under två sekel (Stockholm 2000). 
of-the-art telescopes, and with their help Swedish astronomers could make observations and draw conclusions impossible in the less advanced Swedish observatories. Again, it was not the research itself, conducted at these observatories, that was of interest, but rather the research possibilities and facilities that the American locations offered. In other disciplines, studies in America were natural because the U.S. had developed theories and methods not available in Europe, partly because the areas of study were interdisciplinary and not yet established in Sweden. Examples of such subjects include Social Work and Home Economics, the latter with its own department at Cornell University. ${ }^{23}$

The Sweden-America Foundation was founded in the immediate aftermath of World War I, which no doubt played an important role for its establishment. ${ }^{24}$ Social Democratic Leader and Prime Minister-to-be Hjalmar Branting was one participant at the founding meeting in 1919 and later served as a member of the board. To Branting, Wilsonian America was a champion for peace and-at this time-the strongest advocate of democracy and opponent of absolutism. Closer connections between America and Europe through institutions such as the Sweden-America Foundation would minimize the risk of another great war and strengthen democracy. Branting also seems to have been curious about the American unit-wage system, as a more just and less exploitative method of compensating the workers for their efforts. ${ }^{25}$

For the individual fellow, the benefits of travelling to America during this period could be plentiful. Transatlantic travel was costly and access to American higher education was limited. The exclusivity of studying in the United States brought the fellows significant symbolic gains, in addition to the theoretical and practical knowledge and experience they acquired. ${ }^{26}$

23 National Archives, Stockholm, Sverige-Amerika Stiftelsens arkiv, A2: "Styrelseprotokoll med bilagor", "Arbetsutskottets sammanträde," 13 October 1921, Appendix, pp. 4-5.

24 This point is evolved in Dag Blanck's "Scholars across the seas" in this issue, with special emphasis also on the perceived need to improve the image of Sweden in America after the war.

25 Hjalmar Branting, "Vågen stiger": En ögonblicksbild av världsläget (Stockholm 1917), 10-16. The idea of the benefits of transatlantic connections for the sake of peace appears to have been present also in the Swedish church's contact with its American sister church, during this time. See the foreword to Fran Upsala till Rock Island: en predikofärd i nya världen (Stockholm 1924), pp. 7-10, by Nathan Söderblom, archbishop and member of the board of the Sweden-America Foundation.

26 In Mikael Börjesson, Transnationella utbildningsstrategier vid svenska lärosäten och bland svenska studenter i Paris och New York (Uppsala 2005), pp. 553-558, there is a discussion of the individual's gain from study abroad. His conclusion is based on contemporary material, and his argument evolves around 
At times, the Foundation was also concerned that the fellowship program would cause Sweden to lose valuable citizens it hardly could afford to do without. ${ }^{27}$ However, at the tenth anniversary, the vice president of the board proudly noted that every single fellow had returned, with significantly improved chances to pursue successful careers in their homeland, ${ }^{28}$ a receiptalbeit skewed-as good as any of the convertibility of their transnationally acquired capitals, and perhaps also of the national usefulness of the American experiences - regardless of their nature.

the assets the individual acquires through his or her time spent at a more or less prestigious institution (and as I have demonstrated here, most of the academic fellows visited extremely high prestige universities), a culturally or financially important city or just by being abroad. For the individual, different kinds of capitals (through a bourdieuean framework) are acquired: symbolic, educational, field and place specific, etc. See also Mikael Börjesson's contribution "Location and education" in this issue.

27 Sweden-America Foundation, Årsberättelse 1923 (Stockholm 1923), p. 1.

28 Sweden-America Foundation, Sverige-Amerika Stiftelsen. Jubileumsskrift 1919-1929 (Stockholm 1929), p. 26. 